\title{
Molecular characterization of human Echinococcus isolates and the first report of E. canadensis (G6/G7) and E. multilocularis from the Punjab Province of Pakistan using sequence analysis
}

Aisha Khan 1,2,3,4, Haroon Ahmed ${ }^{1 *}$, Sami Simsek ${ }^{5}$, Hua Liu ${ }^{2,3,4}$, Jianhai Yinn ${ }^{2,3,4}$, Ying Wang ${ }^{2,3,4}$, Yujuan Shen ${ }^{2,3,4}$ and Jianping $\mathrm{CaO}^{2,3,4^{*}}$

\begin{abstract}
Background: Echinococcosis is a zoonotic parasitic disease causing serious health problems in both humans and animals in different endemic regions across the world. There are two different forms of human echinococcosis: Cystic Echinococcosis (CE) and Alveolar Echinococcosis (AE). CE is caused by the larval stage of Echinococcus granulosus sensu lato and AE by the larval stage of Echinococcus multilocularis. Geographically, CE is universally distributed, while AE is prevalent in the northern hemisphere. Although the disease is endemic in neighboring countries (China, Iran and India) of Pakistan, there are limited reports from that country. Besides, there are no comprehensive data on the genotyping of Echinococcus species in humans based on sequence analysis. This study aimed to detect the presence of human CE and to identify Echinococcus spp. in human isolates through genetic characterization of hydatid cysts in the Punjab Province of Pakistan.
\end{abstract}

Methods: Genetic analysis was performed on 38 human hydatid cyst samples collected from patients with echinococcosis using mitochondrial cytochrome c oxidase subunit 1 (cox1), cytochrome b (cytb) and NADH subunit 1 (nad1). Patient data including age, epidemiological history, sex, and location were obtained from hospital records.

Results: According to the sequence analysis we detected E. granulosus sensu stricto $(n=35)$, E. canadensis (G6/G7) $(n=2)$, and E. multilocularis $(n=1)$. Thus, the majority of the patients $(92.1 \%, 35 / 38)$ were infected with E. granulosus s.S. This is the first molecular confirmation of $E$. canadensis (G6/G7) and E. multilocularis in human subjects from Pakistan.

Conclusions: These findings suggested that E. granulosus s.s. is the dominant species in humans in Pakistan. In addition, E. canadensis (G6/G7) and E. multilocularis are circulating in the country. Further studies are required to explore the genetic diversity in both humans and livestock.

Keywords: E. granulosus sensu stricto, E. canadensis, E. multilocularis, Human, Genotyping, Pakistan

\footnotetext{
*Correspondence: haroonahmad12@yahoo.com; caojp@yahoo.com

'Department of Biosciences, COMSATS University Islamabad (CUI), Islamabad,

Pakistan

${ }^{2}$ Key Laboratory of Parasite and Vector Biology, MOH, Shanghai, China

Full list of author information is available at the end of the article
}

(c) The Author(s). 2020 Open Access This article is licensed under a Creative Commons Attribution 4.0 International License, which permits use, sharing, adaptation, distribution and reproduction in any medium or format, as long as you give appropriate credit to the original author(s) and the source, provide a link to the Creative Commons licence, and indicate if changes were made. The images or other third party material in this article are included in the article's Creative Commons licence, unless indicated otherwise in a credit line to the material. If material is not included in the article's Creative Commons licence and your intended use is not permitted by statutory regulation or exceeds the permitted use, you will need to obtain permission directly from the copyright holder. To view a copy of this licence, visit http://creativecommons.org/licenses/by/4.0/ The Creative Commons Public Domain Dedication waiver (http://creativecommons.org/publicdomain/zero/1.0/) applies to the data made available in this article, unless otherwise stated in a credit line to the data. 


\section{Background}

Echinococcosis is a zoonotic disease caused by tapeworm parasites belonging to the Echinococcus genus. There are two main types of echinococcosis: Cystic Echinococcosis (CE) caused by Echinococcus granulosus sensu lato and Alveolar Echinococcosis (AE) caused by E. multilocularis. Additionally, polycystic echinococcosis (caused by E. vogeli and E. oligarthra) also occurs predominantly in South America [1]. CE has a worldwide geographical distribution [2]. Echinococcosis disrupts the economies of many countries, affecting approximately 2-3 million people [3]. The estimated human burden of CE was below 1 million disability adjusted life years (DALYs), but may increase above this figure. Annual losses caused by CE might reach 20 million US dollars [4]. The disease has a prevalence of about $1 / 100,000$ in developed countries and can reach 200/100,000 in rural populations having close contact with domestic dogs [3].

Most species of Echinococcus inhabit domestic and wild mammals. The definitive hosts include both domesticated dogs and wild carnivore species (foxes, wolves and coyotes). Humans and livestock act as intermediate hosts. Livestock animals are the intermediate hosts for E. granulosus s.s., while wild small mammals serve for $E$. multilocularis. Humans acquire infection with CE by accidental ingestion of parasite eggs in the contaminated food and water, or by direct interaction with the definitive hosts [5]. Hatching of eggs occurs in small intestine and then the developing parasite larvae can spread to any other organ; however, they prefer to reside in the liver, where parasite forms the hydatid cysts [6]. Molecular genotyping has shown that members of E. granulosus s.l. include E. granulosus s.s. (G1-G3), E. equinus (G4), E. ortleppi (G5), E. canadensis (G6/7, and G8-10) and E. felidis [2].

There are limited data about CE in Pakistan, whereas the incidence of the disease is high in neighboring countries such as Iran, India, and China, for which published data are available for both prevalence and genotyping. Limited research has been conducted on echinococcosis in the past decade in Pakistan [7]. Previous investigations of Pakistani isolates showed the incidence of E. granulosus s.s. (G1-G3) in cattle, buffalo and sheep, while in humans, E. granulosus s.s. (G1-G3) and E. canadensis (G6/7) were detected based on data using the $\operatorname{cox} 1$ gene sequences [810]. However, interestingly, E. multilocularis was reported in cattle from Pakistan $[10,11]$. In the past, E. granulosus s.s. was reported in livestock (e.g.,cattle), while E. granulosus s.s. and the former G6 genotype were reported by using polymerase chain reaction-restriction fragment length polymorphism (PCR-RFLP) analysis without confirmation by gene sequencing in humans in Khyber Pakhtunkhwa (KPK) province of Pakistan [11].
Therefore, in the current study, hydatid cyst samples collected from human patients with echinococcosis and stored as formalin-fixed paraffin-embedded (FFPE) tissues were subjected to sequence analysis by analyzing mitochondrial cytochrome $c$ oxidase subunit 1 ( $\operatorname{cox} 1)$, cytochrome $b(c y t b)$, and NADH subunit 1 (nad1) genes, to investigate the possible genetic diversity in the hydatid cyst samples in Pakistan.

\section{Methods}

Geography of the study area

Punjab is one of the largest provinces by population, with fertile agricultural land and deserts in the southern part near the border with Rajasthan and near the Sulaiman Range. Punjab comprises parts of the Cholistan and Thal deserts. It has extreme weather, with foggy and wet winters. The average temperature increases from midFebruary, with springtime weather continuing until midApril, when the summer heat sets in June and July are very hot months.

\section{Collection of samples}

The formalin fixed and paraffin embedded hydatid cyst samples were collected from the Pathology Departments of the contributing hospitals from 2012 to 2017. All patients were confirmed as being infected with echinococcosis (CE, $n=37$; AE, $n=1$ ) by histopathological investigation after surgery (detection of Periodic AcidSchiff (PAS)-positive laminated layers, and or protoscoleces and/or hooklets). Patient data, including age, sex, and epidemiological history were recorded.

\section{Molecular analysis \\ Genomic DNA extraction}

The genomic DNA (gDNA) isolation was performed using individual Formalin-fixed paraffin-embedded (FFPE) tissues. Sections of $10-15 \mu \mathrm{m}$ thickness were taken from each cyst by using astndard microtome (Leica SM2000 R Sliding Microtome,Wetzlar, Germany) with disposable DNA-RNA free blades. Equipment was autoclaved or sanitized before use. Paraffin was removed by incubation in $1 \mathrm{ml}$ of xylene for $10 \mathrm{~min}$ at $37^{\circ} \mathrm{C}$. The supernatant was discarded after centrifugation at $12000 \times g$ for $5 \mathrm{~min}$. Samples were rehydrated in descending ethanol concentrations; excess ethanol was evaporated at room temperature. A genomic DNA isolation kit (TRANS Easy Pure FFPE Tissue Genomic DNA Kit, Code: EE191-01; Transgen biotech, Beijing, China) was used to extract total gDNA according to the manufacturer's protocol, with a few modifications. Briefly, the tissue samples were digested at $56{ }^{\circ} \mathrm{C}$ overnight in lysis buffer $(400 \mu \mathrm{l})$, and then the gDNA was extracted. Sterile distilled water $(100 \mu \mathrm{l})$ was used to resuspend the pellet. 
The gDNA samples were stored at $-20^{\circ} \mathrm{C}$ until further use [12].

\section{$P C R$ amplification and sequencing}

The mitochondrial genes ( $\operatorname{cox} 1$, nad1, and $c y t b$ ) were amplified from the isolated gDNA as previously described [12, 13]. Amplification of the cox1 (446 bp) and $c y t b$ genes $(580 \mathrm{bp})$ was carried out using a thermocycler with the following PCR conditions: denaturation was done at $94{ }^{\circ} \mathrm{C}$ for $30 \mathrm{~s}$, annealing at $54{ }^{\circ} \mathrm{C}$ for $30 \mathrm{~s}$ and extension at $72{ }^{\circ} \mathrm{C}$ for $60 \mathrm{~s}$, for 35 cycles. Amplification of the nad1 gene ( $900 \mathrm{bp}$ ) was performed with the following PCR conditions: denaturation at $95^{\circ} \mathrm{C}$ for $60 \mathrm{~s}$, annealing was done at $50^{\circ} \mathrm{C}$ for $50 \mathrm{~s}$ and extension at $72{ }^{\circ} \mathrm{C}$ for $70 \mathrm{~s}$, for 30 cycles [14]. All PCR amplifications were performed with a negative control comprising sterile distilled water instead of the DNA template. The PCR products were visualized using a gel doc system after separation through a $1.5 \%$ agarose gel. All positive samples PCR products were subjected to sequence analysis.

\section{Phylogenetic analysis}

Construction of the phylogenetic tree, multiple sequence alignment, and unidirectional DNA sequence analysis were constructed using Mega X [15]. A maximum composite likelihood (MCL) strategy was applied to construct the initial trees, using a heuristic search with the BioNJ algorithms and neighbor-joining approach. The superior log-likelihood value was applied to select the topology [70]. The reference sequences that were used as outgroups in the phylogeny and in tree construction are shown in Table 1.

\section{Statistical analysis}

Data was analyzed for statistical analysis by using Fisher's exact test.

\section{Results}

In the present study, 38 human hydatid cyst samples were collected from surgically confirmed patients with echinococcosis, from different areas of Punjab, Pakistan. The average age of the patients with CE was 32.73 (ranging from 5 to 75 years). The demographic characteristics of infected cases are summarized in Table 2.

Among the 38 human echinococcosis samples analyzed, 22 were from males (57.8\%) and 16 (42.2\%) were from females and the differences were not statistically significant $\left(\chi^{2}=1.89, d f=1, P>0.05\right)$. A larger proportion $(76.3 \%)$ of echinococcosis cases was reported from rural areas, which have closer contact or association with dogs compared with that in urban areas (23.7\%). The liver $(50 \%)$ was most affected organ, followed by the lungs (22.5\%), and others (Table 2).

\section{Genetic characterization of Echinococcus isolates}

PCR amplification of the cox 1 gene yielded a product of $446 \mathrm{bp}$, while $c y t b$ yielded a $580 \mathrm{bp}$ fragment, and nad 1 yielded a $900 \mathrm{bp}$ product in all samples. The nucleotide sequences of all Pakistani samples $(n=38)$ were BLAST searched against reference sequences retrieved from GenBank. According to the BLAST analysis of the sequences of the cox1, cytb, and nad1 genes, E. granulosus s.s. $(n=35)$, E. canadensis (G6/G7) $(n=2)$, and E. multilocularis $(n=1)$ were detected. The findings showed that majority of the patients (35/38) were infected with $E$. granulosus s.s. All sequences have been published in GeneBank (acession no: MK229294-MK229342).

E. granulosus s.s. and E. canadensis (G6/G7) were characterized by using the sequences of cox1 (446 bp), cytb (580 bp), and nad1 (900 bp). Each sample was characterized by using the sequence at least one of them while $E$. multilocularis was identified by using only $c y t b$ (580 bp).

\section{Alignment results of the sequences}

In the sequence comparison, the cox 1 gene showed $100 \%$ match with E. granulosus s.s. except for isolates PUN-23 and PUN-91 were identified as E. canadensis (G6/G7) (Fig. 1a).

The $c y t b$ gene sequences matched with the selected reference gene sequences of E. granulosus s.s. However, only PUN-91 was identical with the E. canadensis (G6/ G7) reference gene sequence (Fig. 1b).

For the nad1 gene, while the PUN-91 sequence matched with $E$. canadensis (G6/G7), all the other sequences were detected as E. granulosus s.s. after BLAST analysis (Fig. 1c).

Two samples were characterized as containing $E$. canadensis (G6/G7) based on cox1 (446 bp). They were $100 \%$ identical and showed $100 \%$ similarity with a pig G6 isolate (GenBank: JQ356716) from France and 99.8\% similarity with a human G6 isolate (GenBank: AB893260) from Mongolia (Fig. 1a). However, only one of them was identified as being E. canadensis (G6/G7) using the nad1 and cytb sequences (Fig. 1b, c). The current study reveals the first report of genotype $E$. canadensis (G6/G7) in humans from the Punjab province in Pakistan (Table 3). The Pakistani isolate (PK-91) had $99.6 \%$ similarity with a G6 genotype (GenBank: MH300954) from Mauritania and with a human G6 genotype (GenBank: MH300938) from Kenya (Fig. 1c).

One $c y t b$ gene sequence $(580 \mathrm{bp})$ was identified as $E$. multilocularis and it was $100 \%$ identical to isolates from China (GenBank: KY290787 and KY290785), 99.8\% identical to isolates from foxes in Poland (GenBank: KY205676 and KY205667), and 99.6\% identical to an isolate from a fox in France (GenBank: AB461396). Meanwhile, the Pakistani strains were genetically distant 
Table 1 Provenance and GenBank accessions for the reference sequences used in the phylogenetic analyses

\begin{tabular}{|c|c|c|c|c|}
\hline $\begin{array}{l}\text { Species/ } \\
\text { Marker }\end{array}$ & $\operatorname{cox} 1$ & cytb & nad1 & Reference \\
\hline \multirow{7}{*}{$\begin{array}{l}\text { E. granulosus } \\
\text { (s.s.) }\end{array}$} & Portugal (HF947554) & & & [16] \\
\hline & $\begin{array}{l}\text { Argentina (MG672207) } \\
\text { Algeria (MG672288) } \\
\text { Greece (MG672282) } \\
\text { Australia (MG672263) } \\
\text { Mexico (MG672259) } \\
\text { Tunisia (MG672171) } \\
\text { Turkey (MG682535) }\end{array}$ & $\begin{array}{l}\text { Algeria (MG672293) } \\
\text { Iran (MG672246) } \\
\text { Algeria (MG682544) } \\
\text { Iran (MG682539) } \\
\text { Spain (MG682527) Turkey } \\
\text { (MG682536) }\end{array}$ & $\begin{array}{l}\text { Algeria (MG672293) } \\
\text { Greece (MG672282) } \\
\text { Mexico (MG672259) } \\
\text { Mongolia (MG672254) } \\
\text { Finland (MG682511) India (MG682512) Albania } \\
\text { (MG682514) Romania (MG682516) Turkey (MG682535) } \\
\text { Italy (MG682521) Iran (MG682541) Turkey (MG682531) }\end{array}$ & [17] \\
\hline & $\begin{array}{l}\text { Greece (KU925430) Romania } \\
\text { (KU925431) Spain (KU925419) }\end{array}$ & & & [18] \\
\hline & $\begin{array}{l}\text { Turkey (KY766888) Iran } \\
\text { (KY766899) Morocco } \\
\text { (EF367275) France } \\
\text { (KY766892) }\end{array}$ & & France (KY766893) & [19] \\
\hline & Brazil (KT382540) ${ }^{\mathrm{a}}$ & & & - \\
\hline & Argentina (KX039948) & & & [20] \\
\hline & Palestine (KC109658) & & & [21] \\
\hline \multirow[t]{3}{*}{ E. equinus } & Turkey (KY766905) & Turkey (KY766905) & Turkey (KY766905) & [19] \\
\hline & UK (AB786665) & UK (AB786665) & & [22] \\
\hline & & & Germany (GQ420652) & [23] \\
\hline \multirow[t]{2}{*}{ E. ortleppi } & & & India (KY766908) & [19] \\
\hline & & & Japan (AB235846) & [2] \\
\hline \multirow{8}{*}{$\begin{array}{l}\text { E. } \\
\text { canadensis } \\
(G 6 / G 7)\end{array}$} & Kenya (KX010838) & & & [24] \\
\hline & & $\begin{array}{l}\text { Mauritania (MH300954) Sudan } \\
\text { (MH300948) Kenya (MH300938) } \\
\text { Argentina (MH300934) } \\
\text { Lithuania (MH301020) } \\
\text { Ukraine (MH301022) } \\
\text { France (MH300997) }\end{array}$ & Sudan (MH300939) Lithuani (MH301020) & [25] \\
\hline & Mongolia (AB893260) & & & [26] \\
\hline & Japan (AB235847) & & & [2] \\
\hline & Peru (AB777925) & & & [27] \\
\hline & Mongolia (AB271236) ${ }^{a}$ & & & - \\
\hline & & China (MG597240) & & - \\
\hline & & Japan (AB745463) & & [22] \\
\hline \multirow[t]{7}{*}{$\begin{array}{l}\text { E. } \\
\text { multilocularis }\end{array}$} & & $\begin{array}{l}\text { China (KY290787, KY290785, } \\
\text { MF370869, MF370870) }\end{array}$ & & - \\
\hline & & China (KT965467) & & [28] \\
\hline & & $\begin{array}{l}\text { Poland (KY205667, KY205676, } \\
\text { KY205670) }\end{array}$ & & [29] \\
\hline & & Canada (KC549999, KC550006) & & [30] \\
\hline & & $\begin{array}{l}\text { Slovakia (AB461397) Japan } \\
\text { (AB461399, AB477009) } \\
\text { France (AB461396) Kazakhstan } \\
\text { (AB461398) Mongolia (AB461402) }\end{array}$ & & [31] \\
\hline & & Canada (JF751035) & & [32] \\
\hline & & Japan (AB018440) & & \\
\hline
\end{tabular}


Table 2 Epidemiological and clinical information for 38 patients with echinococcosis

\begin{tabular}{|c|c|c|}
\hline Parameter & Factor & $n(\%)$ \\
\hline \multirow[t]{2}{*}{ Sex } & Male & $22(57.8)$ \\
\hline & Female & $16(42.2)$ \\
\hline \multirow[t]{2}{*}{ Housing location } & Urban & $9(23.7)$ \\
\hline & Rural & $29(76.3)$ \\
\hline \multirow[t]{2}{*}{ Contact with stray dogs } & Yes & $23(60.5)$ \\
\hline & No & $15(39.5)$ \\
\hline \multirow[t]{12}{*}{ Cyst location } & Liver & $19(50.0)$ \\
\hline & Lung & $8(22.5)$ \\
\hline & Spleen & $1(2.5)$ \\
\hline & Right side of pelvis & $1(2.5)$ \\
\hline & Right forearm & $1(2.5)$ \\
\hline & Gall-bladder & $1(2.5)$ \\
\hline & Kidney & $2(5.0)$ \\
\hline & Extradural cyst & $1(2.5)$ \\
\hline & Kidney & $1(2.5)$ \\
\hline & Hypochondrium & $1(2.5)$ \\
\hline & Hepatogastric omentum & $1(2.5)$ \\
\hline & Orbital biopsy & $1(2.5)$ \\
\hline \multirow[t]{3}{*}{ Cyst size } & Large & $13(34.3)$ \\
\hline & Medium & $05(13.1)$ \\
\hline & Small & $20(52.6)$ \\
\hline \multirow[t]{2}{*}{ Therapy with albendazole } & Administered & $36(94.7)$ \\
\hline & Not administered & $02(5.3)$ \\
\hline \multirow[t]{3}{*}{ Serology } & Positive & $13(34.2)$ \\
\hline & Negative & $02(5.3)$ \\
\hline & Data not available & $23(60.5)$ \\
\hline
\end{tabular}

from the Mongolian and Canadian strains, as shown in the phylogenetic tree (Fig. 1d).

The cytb gene from the Pakistan samples of E. granulosus (s.s.) showed $100 \%$ similarity with the other selected reference sequences. All other compared G6, G7, and G10 samples, including the samples from Pakistan, showed the same sequences (Fig. 2).

For the nad1 gene, PUN-131-Pakistan was conserved when compared with the selected genotypes, whereas point mutations and substitutions were found in some of the other compared sequences (Fig. 3). The PUN116-Pakistan sample had point mutations reported from France (GenBank: KY766893) and Turkey, while other sequences of E. granulosus (s.s.) were conserved (Fig. 4).

\section{Discussion}

The two notable cestode-borne zoonoses are $\mathrm{CE}$ and AE. In the northern hemisphere, AE is widely distributed, while $\mathrm{CE}$ is widely distributed across the world and the disease burden in humans is highly variable in different endemic areas. $\mathrm{AE}$ and $\mathrm{CE}$ are still considered as neglected zoonoses in many areas of the world, although their prevalence is quite high in such areas, because of lack of awareness and disease management. The occurrence of $\mathrm{CE}$ is quite high around the world; however, the pathogenicity and fatality caused by $\mathrm{AE}$ is more prevalent in Asia [33]. CE is an endemic disease in Pakistan and causes serious economic losses in terms of human healthcare and livestock agriculture costs. In addition, there is lack of knowledge about CE in Pakistan that affects its transmission dynamics [34-36]. Agriculture is the backbone of the Pakistan and a large number of families are affiliated with this sector, including animal rearing and dairy farming for milk products. In small and domestic farms, standard principles are often not strictly followed; therefore, these populations are at high risk of acquiring Echinococcus spp. infection [7]. CE is considered a socially constructed disease because of various traditional practices found among different ethnic groups around the globe, such as keeping many dogs and a large amount of livestock, and the culture of rescuing stray dogs [37].

In current investigation, a total of 35 hydatid cyst samples were characterized as resulting from E. granulosus s.s. A high rate of E. granulosus s.s. was detected, which is in line with the data reported previously in humans (88.5\%) [38] and livestock [39]. Similarly, in China, the majority $(60 \%)$ of $\mathrm{CE}$ positive cases in humans are caused by E. granulosus s.s. (formerly the G1 strain) [40], which also caused $40.62 \%$ of the infections reported in India [41]. However, there is little information on the genetic characterization of Echinococcus spp. in humans in Pakistan. Echinococcus granulosus s.s. has been reported in buffaloes in Sindh Province of Pakistan [8]. This species was detected in small and large ruminants, while the sheep strain (G1) was found in human samples $(n=2)$ using cox1 gene sequencing [9]. Echinococcus granulosus s.s. in cattle has been reported in Pakistan [10]. The high rate of E. granulosus s.s. reported in current study might be because $E$. granulosus s.s. is the predominant species in Pakistan (so far) and in neighbouring countries $[9,39,40]$. Even globally, E. granulosus s.s. is the most predominant causitive agent of $\mathrm{CE}$ [38]. It has a wide host range, which makes it more dominant in endemic localities even in cases where it occurs in sympatry with other E. granulosus s.l. In addition, it might reflect the fact that the maximum number of cases with CE were inhabiting in rural areas, where people have a close association with dogs [41].

In the present study, two samples were characterized as being infected with E. canadensis (G6/G7). E. canadensis (G6/7) was thought to be less infective to humans [42]. It is now known to be the second most important 


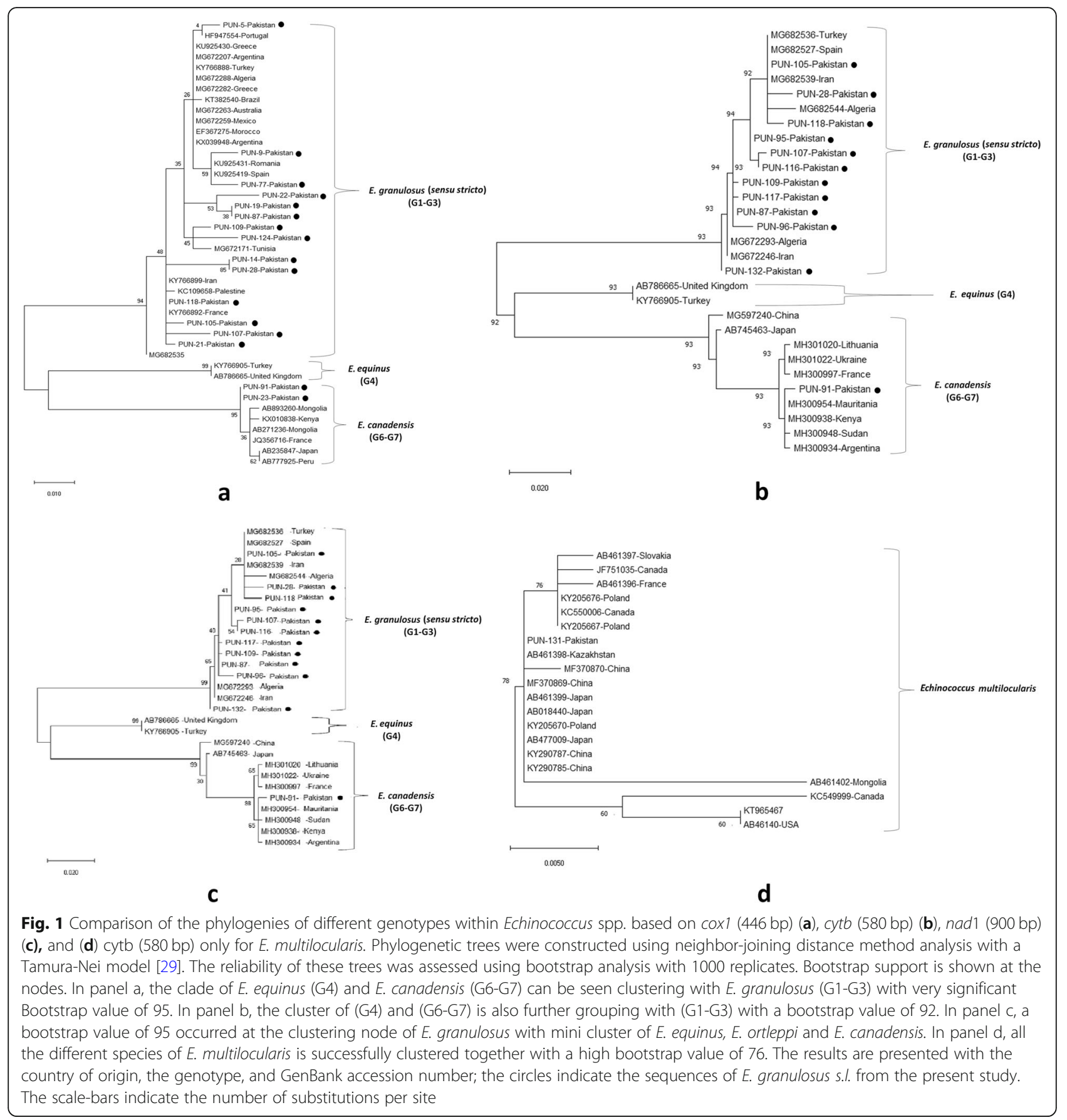

causative agent of CE after E. granulosus s.s [38]. Globally, E. canadensis $(\mathrm{G6} / 7)$ has been reported in Kenya [42, 43]; Argentina [44]; China [40]; in different parts of Africa, Asia, and South America [12, 27, 45]; and in many countries in eastern and south-eastern Europe [27, 46, 47]. Meanwhile, the G6-G10 cluster was reported in Northern Palearctic, Northern Africa, and in the Middle East [27]. In Pakistan, because of the camel and pig populations, G6 transmission to human hosts is possible, especially resulting from camel slaughtering and cross boundary migration of animals from Afghanistan. The characterization of the $E$. canadensis $(\mathrm{G6} / \mathrm{G} 7)$ in humans in Pakistan suggests the interaction between the cameldog and pig-dog cycles. In Pakistan, the pig population is abundant and imposes a serious health threat to the human population. Often, wild pigs live near human settlements in Pakistan. Although the camel population is quite low in the Punjab Province of Pakistan, sharing a border with Afghanistan and Iran means that species transmission is possible because of illegal animal 
Table 3 Genotype assigned in relation to patient age, sex, and cyst localization

\begin{tabular}{|c|c|c|}
\hline Parameter & No. of patients (\%) & Genotype assigned \\
\hline \multicolumn{3}{|l|}{ Age (years) } \\
\hline $1-10$ & $3(7.9)^{\mathrm{a}}$ & E. granulosus s.s. \\
\hline $11-20$ & $6(15.8)^{\mathrm{a}}$ & E. granulosus s.S.; E. canadensis (G6/G7) \\
\hline $21-30$ & $12(31.6)^{b}$ & E. granulosus s.s. \\
\hline $31-40$ & $4(10.5)^{\mathrm{a}}$ & E. granulosus s.s.; E. multilocularis \\
\hline $41-50$ & $7(18.4)^{\mathrm{a}}$ & E. granulosus s.s. \\
\hline $51-60$ & $4(10.5)^{a}$ & E. granulosus s.s. \\
\hline$>60$ or $71-80$ & $2(5.3)^{a}$ & E. granulosus s.s. \\
\hline \multicolumn{3}{|l|}{ Sex } \\
\hline Male & $22(57.8)^{c}$ & $\begin{array}{l}\text { E. granulosus s.S.; E. canadensis (G6/7); } \\
\text { E. multilocularis }\end{array}$ \\
\hline Female & $16(42.2)^{c}$ & E. granulosus s.s. \\
\hline \multicolumn{3}{|l|}{ Cyst location } \\
\hline Liver & $19(50.0)^{d}$ & $\begin{array}{l}\text { E. granulosus s.s.; E. multilocularis; } \\
\text { E. canadensis }(G 6 / G 7)\end{array}$ \\
\hline Lung & $8(22.5)^{e}$ & E. granulosus s.s. \\
\hline Spleen & $1(2.5)^{f}$ & E. granulosus s.s. \\
\hline Right side of pelvis & $1(2.5)^{f}$ & E. granulosus s.s. \\
\hline Right forearm & $1(2.5)^{f}$ & E. granulosus s.s. \\
\hline Gall-bladder & $1(2.5)^{f}$ & E. granulosus s.s. \\
\hline Kidney & $2(5.0)^{f}$ & E. granulosus s.S.; E. canadensis (G6/G7) \\
\hline Extradural cyst & $1(2.5)^{f}$ & E. granulosus s.s. \\
\hline Kidney & $1(2.5)^{f}$ & E. granulosus s.s. \\
\hline Hypochondrium & $1(2.5)^{f}$ & E. granulosus s.s. \\
\hline Hepatogastric omentum & $1(2.5)^{f}$ & E. granulosus s.s. \\
\hline Orbital biopsy & $1(2.5)^{f}$ & E. granulosus s.s. \\
\hline
\end{tabular}

$\overline{a, b}$ Age: The different letters indicate statistically significant differences $\left(X^{2}=12.71, d f=6, P=0.41\right)$

' Sex: No statistically significant difference between sexes $\left(x^{2}=1.89, d f=1, P=0.25\right)$

d,e,f Cyst location: The different letters indicate statistically significant differences $\left(x^{2}=61.89, d f=11, P=0.00\right)$

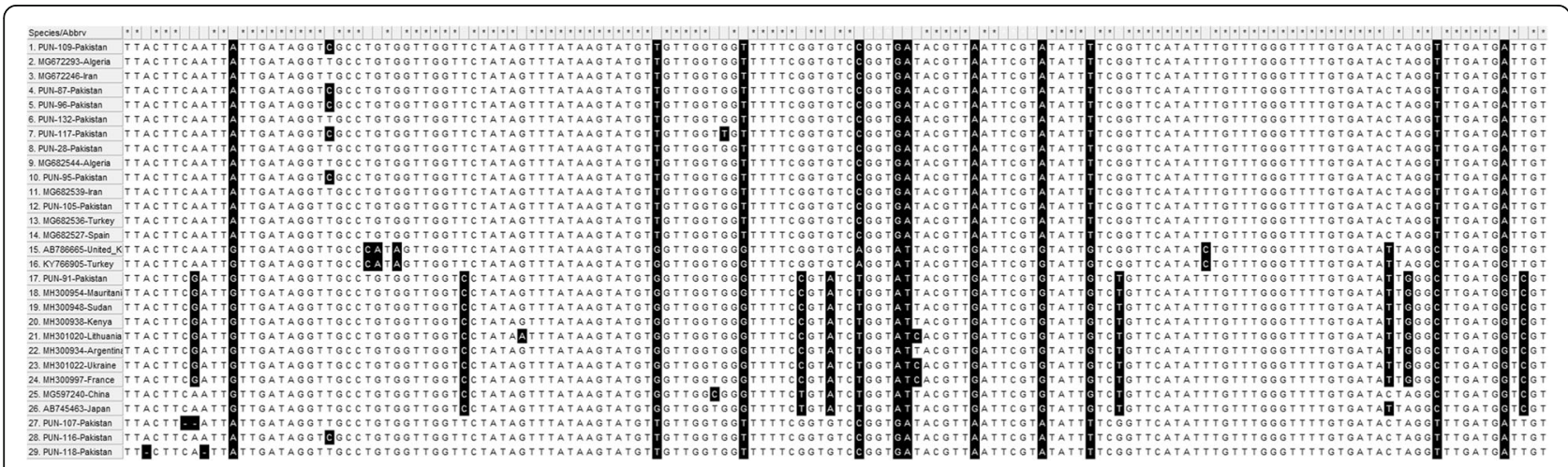

Fig. 2 Multiple sequence alignments of partial cytb gene sequences. Genotypes (G1, G3, G5 and G6), represented with PUN suffixes, were from this study, while reference sequences from GenBank of genotypes G1, G3, G5 and G6 are presented with different codes. The accession numbers range from MK229294 to MK229342 


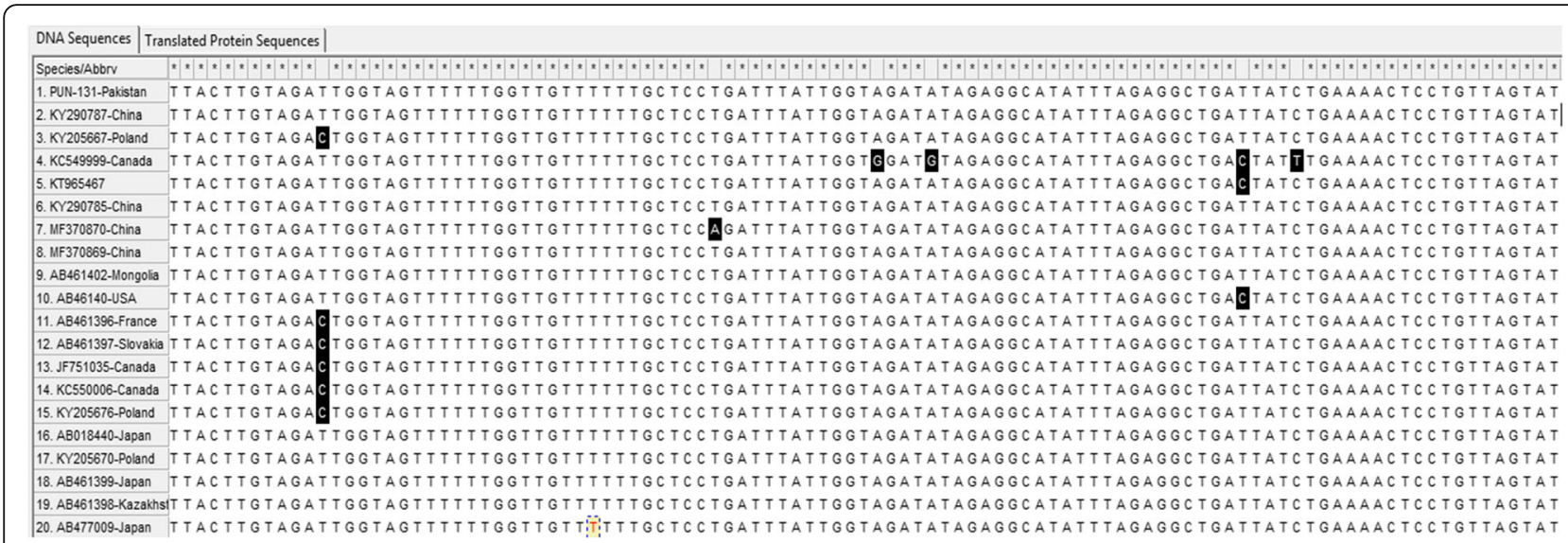

Fig. 3 Multiple sequence alignments of partial cytb gene sequences (E. multilocularis). Genotypes (G1, G3, G5 and G6) represented with PUN suffix were from this study while reference sequences from GenBank of genotypes G1, G3, G5 and G6 are presented with different codes. The accession numbers range from MK229294 to MK229342

transport across the border. Camels and other livestock animals live together; therefore, there is a possibility of exposure to other genotypes through interaction with the common definitive hosts, especially dogs. We could not compare our samples with Afghanistan isolates because there are no E. granulosus sequences from Afganistan deposited in GenBank.

In the present study, one sample was characterized as being infected with $E$. multilocularis. In North America, human cases of $\mathrm{AE}$ caused by $E$. multilocularis have been reported $[48,49]$. $\mathrm{AE}$ is also prevalent in the northern hemisphere and even in the neighbouring country of Afghanistan [33]. In Pakistan echinococoosis ingeglected yet [50, 51].
The current study is first report of genotyping of E. multilocularis from humans in Punjab Province, Pakistan using sequence analysis. Previously, $E$. multilocularis was investigated in cattle from the KPK province of Pakistan as assessed using PCR-RFP [11]. The present findings suggest that cystic echinococcosis is an important emerging health issue and that $\mathrm{AE}$ is circulating in rural areas of Pakistan.

\section{Conclusions}

In conclusion, the current findings indicate the presence of E. granulosus s.s., E. canadensis (G6/G7), and E. multilocularis in the Punjab province of Pakistan. Additionally, E. canadensis (G6/G7) in human isolates is reported

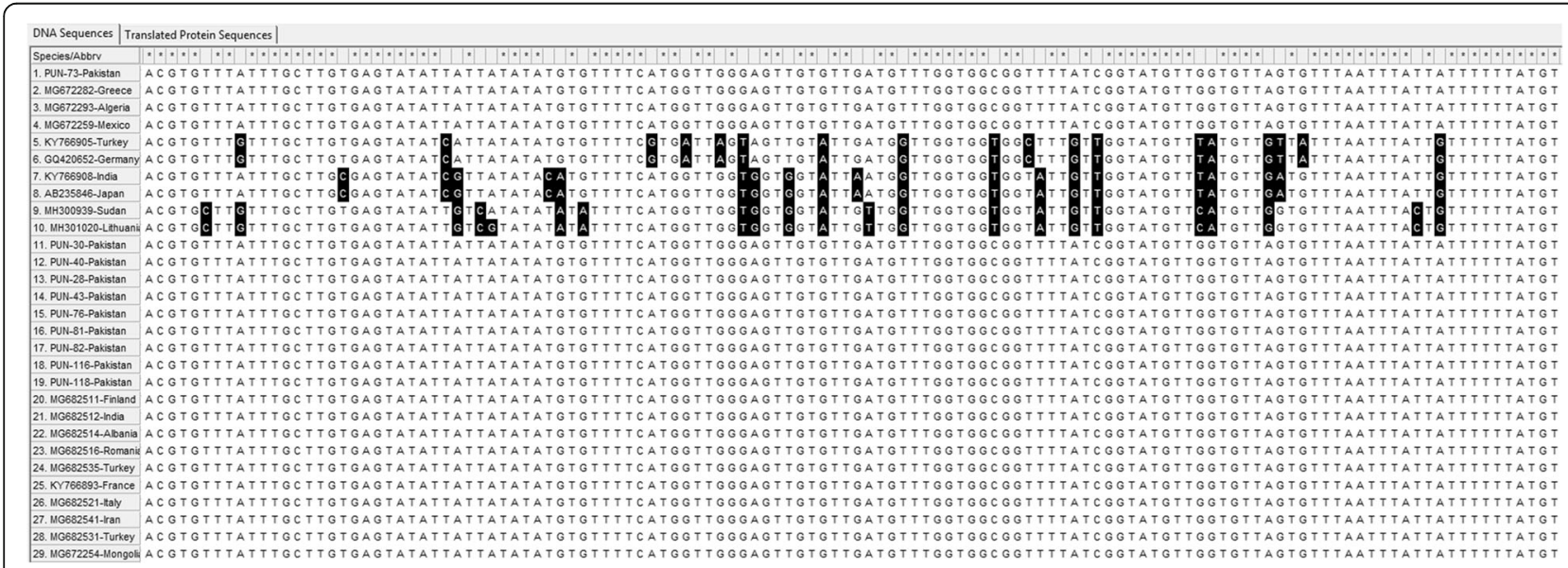

Fig. 4 Multiple sequence alignments of partial nad1 gene sequences. Genotypes (G1, G3, G5 and G6), represented with PUN suffixes, were from this study, while reference sequences from GenBank of genotypes G1, G3, G5 and G6 are presented with different codes. The accession numbers range from MK229294 to MK229342 
for the first time in Pakistan. To aid the eradication of the disease, comprehensive surveillance should be initiated. Control measures developed based on surveillance results could help to slow down the spread of the disease. The probable occurrence of other E. granulosus s.l. species indicate that further epidemiological studies using more Echinococcus isolates from all intermediate hosts (e.g. human and others), as well as definitive hosts, should be performed in different climatic regions of Pakistan.

\section{Abbreviations}

CE: Cystic echinococcosis; AE: Alveolar echinococcosis; FFPE: Formalin-fixed paraffin-embedded tissues; PAS: Periodic acid-Schiff

\section{Acknowledgments}

The authors would like to thank Professor Wenqin Wang at Shanghai Jiaotong University for her help with the bioinformatics analysis, and Dr. Wang Yanjuan at National Institute of Parasitic Diseases, Chinese Center for Disease Control and Prevention for her technical guidance.

\section{Authors' contributions}

AK, HA and JC conceived and designed the study. AK, SS, HL, JY, YW, and YS performed the experiments and data analysis. HA, JC and YS contributed reagents and materials. AK wrote, and $J C$ and $\mathrm{HA}$ revised the paper. All authors read and approved the final manuscript.

\section{Funding}

This study was supported by the National Natural Science Foundation of China (Nos. 81772225 and 81971969 to JC, No. 81772224 to YS), the Chinese Special Programme for Scientific Research of Public Health (No. 201502021 to JC) and the Laboratory of Parasite and Vector Biology, MOH, China (No. WSBKFKT2017-01 to AK). The funders had no role in the study design, data collection and analysis, the decision to publish, or preparation of the manuscript.

\section{Availability of data and materials}

The datasets supporting the conclusions of this article are included within the article. The data ia avaliable for cytb, cox 1 \& nad 1 accession numbers ranged from MK229294 to MK229342 under https://www.ncbi.nlm.nih.gov/ pmc/about/intro/.

\section{Ethics approval and consent to participate}

The Departmental Ethics Review Board (ERB) at the COMSATS University Islamabad (CUI), Pakistan, under ERB/18/72, approved this research study. Informed written consent was obtained from the adult subjects for surgery. The consent was taken from participants and in case of children the consent was obtained from the parents/guardians of the minors included in this study (minors are considered anyone under the age of 16). The hydatid cysts samples (FFPE tissues) obtained after surgery from the Pathology Department were anonymized and the patients' names do not appear in this study.

\section{Consent for publication}

Not applicable because in this study, parasite specimens/cysts obtained postsurgically were used. Patient information was obtained from medical records following surgery, which was sufficiently anonymized so that patients could not be identified.

\section{Competing interests}

The authors declare that they have no competing interests.

\section{Author details}

'Department of Biosciences, COMSATS University Islamabad (CUI), Islamabad, Pakistan. ${ }^{2}$ Key Laboratory of Parasite and Vector Biology, MOH, Shanghai, China. ${ }^{3} \mathrm{WHO}$ Collaborating Centre for Tropical Diseases, Shanghai, China. ${ }^{4}$ National Institute of Parasitic Diseases, Chinese Center for Disease Control and Prevention, Shanghai, China. ${ }^{5}$ Department of Parasitology, Faculty of Veterinary Medicine, University of Firat, 23119 Elazig, Turkey.

Received: 23 July 2019 Accepted: 24 March 2020

Published online: 03 April 2020

\section{References}

1. Moro P, Schantz PS. Echinococcosis: a review. Int J Infect Dis. 2008;13:12533.

2. Nakao M, McManus D, Schantz P, Craig P, Ito A. A molecular phylogeny of the genus Echinococcus inferred from complete mitochondrial genomes. Parasitology. 2007;134:713-22.

3. OIE. Echinococcosis or Hydatidosis. http://www.oie.int/animal-health-in-theworld/animal-diseases/echinococcosis/. Accessed 28 May 2019.

4. Budke CM, Deplazes P, Torgerson PR. Global socioeconomic impact of cystic echinococcosis. Emerg Infect Dis. 2006;12:296-303.

5. Ito A, Budke CM. The echinococcosis in Asia: the present situation. Acta Trop. 2016;176:11-21.

6. Eckert J, Deplazes P. Biological, epidemiological, and clinical aspects of echinococcosis, a zoonosis of increasing concern. Clin Microbiol Rev. 2004 17:107-35.

7. Ahmed H, Ali S, Afzal MS, Khan AA, Raza H, Shah ZH, Simsek S. Why more research needs to be done on echinococcosis in Pakistan. Infect Dis Poverty. 2017:6:90

8. Ehsan M, Akhter N, Bhutto B, Arijo A, Gadahi A. Prevalence and genotypic characterization of bovine Echinococcus granulosus isolates by using cytochrome oxidase 1 (CO1) gene in Hyderabad. Pakistan Vet Parasitol. 2017:239:80-5.

9. Latif AA, Tanveer A, Maqbool A, Siddiqi N, Kyaw-Tanner M, Traub RJ. Morphological and molecular characterisation of Echinococcus granulosus in livestock and humans in Punjab, Pakistan. Vet Parasitol. 2010;170:44-9.

10. Khan A, Ahmed H, Simsek S. Molecular epidemiology of Echinococcus species in Pakistan. Asian Pacific J Trop Med. 2018;13:36.

11. Ali I, Panni MK, lqbal A, Munir I, Ahmad S, Ali A. Molecular characterization of Echinococcus species in Khyber Pakhtunkhwa, Pakistan. Acta Scientiae Veterinariae. 2015:43:1277.

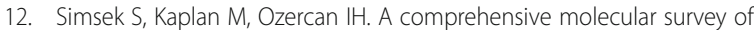
Echinococcus granulosus in formalin-fixed paraffin-embedded tissues in human isolates in Turkey. Parasitol Res. 2011;109:411-6.

13. Xiao N, Qiu J, Nakao M, Nakaya K, Yamasaki H. Identification of Echinococcus species from a yak in the Qinghai-Tibet plateau region of China. Am J Trop Med Hyg. 2003;69:445-6

14. Yang J, Jia W, Jing T, Tian G, Cheng X. Analysis of genetic variation of Echinococcus granulosus collected from three provinces in China. Chin J Vet Sci Tech. 2004;34:12-6.

15. Kumar S, Stecher G, Li M, Knyaz C, Tamura K. MEGA X: Molecular evolutionary genetics analysis across computing platforms. Mol Biol and Evol. 2018:35:1547-9.

16. Kinkar L, Laurimae T, Acosta-Jamett G, Andresiuk V, Balkaya I, Casulli A, et al. Global phylogeography and genetic diversity of the zoonotic tapeworm Echinococcus granulosus sensu stricto genotype G1. Int Journal for Parasitol. 2018:48(9-10):729-42.

17. Kinkar L, Laurimae T, Simsek S, Balkaya I, Casulli A, Manfredi MT, et al. Highresolution phylogeography of zoonotic tapeworm Echinococcus granulosus sensu stricto genotype G1 with an emphasis on its distribution in Turkey, Italy and Spain. Parasitology. 2016;143:1790-801.

18. Kinkar L, Laurimae T, Sharbatkhori M, Mirhendi H, Kia EB, Ponce-Gordo F, et al. New mitogenome and nuclear evidence on the phylogeny and taxonomy of the highly zoonotic tapeworm Echinococcus granulosus sensu stricto. Infect Genet Evol. 2017;52:52-8.

19. Laurimae T, Kinkar L, Andresiuk V, Haag KL, Ponce-Gordo F, Acosta-Jamett G, et al. Genetic diversity and phylogeography of highly zoonotic Echinococcus granulosus genotype G1 in the Americas (Argentina, Brazil, Chile and Mexico) based on 8279 bp of mtDNA. Infect Genet Evol. 2016;45:290-6.

20. Adwan G, Adwan K, Bdir S, Abuseir S. Molecular characterization of Echinococcus granulosus isolated from sheep in Palestine. Exp Parasitol. 2013;134:195-9.

21. Nakao M, Yanagida T, Konyaev S, Lavikainen A, Odnokurtsev VA, Zaikov VA, et al. Mitochondrial phylogeny of the genus Echinococcus (Cestoda: Taeniidae) with emphasis on relationships among Echinococcus canadensis genotypes. Parasitology. 2013;140:1625-36. 
22. Blutke A, Hamel D, Huttner M, Gehlen H, Romig T, Pfister K, et al. Cystic echinococcosis due to Echinococcus equinus in a horse from southern Germany. J Vet Diagn Investig. 2010;22:458-62.

23. Addy F, Wassermann M, Banda F, Mbaya H, Aschenborn J, Aschenborn O, et al. Genetic polymorphism and population structure of Echinococcus ortleppi. Parasitology. 2016;144:450-8.

24. Laurimae T, Kinkar L, Romig T, Omer RA, Casulli A, Umhang G, et al. The benefits of analysing complete mitochondrial genomes: deep insights into the phylogeny and population structure of Echinococcus granulosus sensu lato genotypes G6 and G7. Infect Genet Evol. 2018;64:85-94.

25. Ito A, Dorjsuren T, Davaasuren A, Yanagida T, Sako Y, Nakaya K, et al. Cystic echinococcosis in Mongolia: molecular identification, serology and risk factors. PLoS Negl Trop Dis. 2014;8:e2937.

26. Konyaev SV, Yanagida T, Nakao M, Ingovatova GM, Shoykhet YN, Bondarev AY, et al. Genetic diversity of Echinococcus spp. in Russia. Parasitology. 2013; 140:1637-47.

27. Lavikainen A, Lehtinen MJ, Meri T, Hirvela-Koski V, Meri S. Molecular genetic characterization of the Fennoscandian cervid strain, a new genotypic group (G10) of Echinococcus granulosus. Parasitology. 2003;127:207-15.

28. Karamon J, Stojecki K, Samorek-Pierog M, Bilska-Zajac E, Rozycki M, Chmurzynska E, et al. Genetic diversity of Echinococcus multilocularis in red foxes in Poland: the first report of a haplotype of probable Asian origin. Folia Parasitol. 2017;9:64.

29. Gesy KM, Jenkins EJ. Introduced and native haplotypes of Echinococcus multilocularis in wildlife in Saskatchewan. Canada J Wildl Dis. 2015:3:743-8.

30. Nakao M, Xiao N, Okamoto M, Yanagida T, Sako Y, Ito A. Geographic pattern of genetic variation in the fox tapeworm Echinococcus multilocularis. Parasitol Int. 2009:58:384-9.

31. Tamura K, Nei M. Estimation of the number of nucleotide substitutions in the control region of mitochondrial DNA in humans and chimpanzees. Mol Biol Evol. 1993;10:512-26.

32. Jenkins EJ, Peregrine AS, Hill JE, Somers C, Gesy K, Barnes B, et al. Detection of European strain of Echinococcus multilocularis in North America. Emerg Infect Diseases. 2012:18:6-10.

33. Deplazes P, Rinaldi L, Alvarez Rojas CA, Torgerson PR, Harandi MF, Romig T, et al. Global distribution of alveolar and cystic echinococcosis. Adv Parasitol. 2017;95:315-493.

34. Khan A, Naz K, Ahmed H, Simsek S, Afzal MS, Haider W, et al. Knowledge, attitudes and practices related to cystic echinococcosis endemicity in Pakistan. Infect Dis Poverty. 2018:7:4.

35. Khan A, Ahmed H, Simsek S, Afzal MS, Kilinic SG, Kesik HK, et al. A retrospective analysis on the cystic echinococcosis (CE) cases occurred in northeastern Punjab Province. Pakistan Korean J Parasitol. 2018;4:1-6.

36. Khan A, Simsek S, Ahmed H. War, migration and cystic echinococcosis. Travel Med Infect Dis. 2019;28:111-2.

37. Moro PL, Nakao M, Ito A, Schantz PM, Cavero C, Cabrera L. Molecular identification of Echinococcus isolates from Peru. Parasitol Int. 2009:58:184-6.

38. Rojas CAA, Romig T, Lightowlers MW. Echinococcus granulosus sensu lato genotypes infecting humans-review of current knowledge. Int J Parasitol. 2014;44:9-18.

39. Grosso G, Gruttadauria S, Biondi A, Marventano S, Mistretta A. Worldwide epidemiology of liver hydatidosis including the Mediterranean area. World J Gastroenterol. 2012:18:1425-37.

40. Zhang T, Yang D, Zeng Z, Zhao W, Liu A, Piao D, et al. Genetic characterization of human derived hydatid cysts of Echinococcus granulosus sensu lato in Heilongjiang Province and the first report of $\mathrm{G} 7$ genotype of $E$. canadensis in humans in China. PLoS One. 2014;16:e109059.

41. Piccoli L, Bazzocchi C, Brunetti E, Mihailescu P, Bandi C, Mastalier B, et al. Molecular characterization of Echinococcus granulosus in southeastern Romania: evidence of G1-G3 and G6-G10 complexes in humans. Clin Microbiol Infect. 2013;19:578-82.

42. Casulli A, Zeyhle E, Brunetti E, Pozio E, Meroni V, Genco F, et al. Molecular evidence of the camel strain (G6 genotype) of Echinococcus granulosus in humans from Turkana, Kenya. Trans R Soc Trop Med Hyg. 2010;104:29-32.

43. Wachira TM, Bowles J, Zeyhle E, McManus DP. Molecular examination of the sympatry and distribution of sheep and camel strains of Echinococcus granulosus in Kenya. Am J Trop Med Hyg. 1993;48:473-9.

44. Kamenetzky L, Gutierrez AM, Canova SG, Haag KL, Guarnera EL, Parra A, et al. Several strains of Echinococcus granulosus infect livestock and humans in Argentina. Infect Genet Evol. 2002;2:129-36.
45. Mogoye BK, Menezes CN, Wong ML, Stacey S, von Delft D, Wahlers K, et al. First insights into species and genotypes of Echinococcus in South Africa. Vet Parasitol. 2013;196:427-32.

46. Schneider R, Gollackner B, Schindl M, Tucek G, Auer H. Echinococcus canadensis $\mathrm{G} 7$ (pig strain): an underestimated cause of cystic echinococcosis in Austria. Am J Trop Med Hyg. 2010;82:871-4.

47. Turcekova L, Snabel V, D'Amelio S, Busi M, Dubinsky P. Morphological and genetic characterization of Echinococcus granulosus in the Slovak Republic Acta Trop. 2003:85:223-9.

48. Chauchet A, Grenouillet F, Knapp J, Richou C, Delabrousse E, Dentan C, et al. Increased incidence and characteristics of alveolar echinococcosis in patients with immunosuppression-associated conditions. Clin Infect Dis. 2014;59:1095-104.

49. Massolo A, Liccioli S, Budke C, Klein C. Echinococcus multilocularis in North America: the great unknown. Parasite. 2014;21:73.

50. Khan A, Ahmed H, Budke CM. Echinococcosis in Pakistan: a call for research. Lancet Infect Dis. 2019;19(6):581.

51. Khan A, Ahmed H, Simsek S. Make headway for Echinococcosis: take along the ignored cases. Iran J Parasitol. 2019;14(3):497-8.

\section{Publisher's Note}

Springer Nature remains neutral with regard to jurisdictional claims in published maps and institutional affiliations.
Ready to submit your research? Choose BMC and benefit from:

- fast, convenient online submission

- thorough peer review by experienced researchers in your field

- rapid publication on acceptance

- support for research data, including large and complex data types

- gold Open Access which fosters wider collaboration and increased citations

- maximum visibility for your research: over $100 \mathrm{M}$ website views per year

At BMC, research is always in progress.

Learn more biomedcentral.com/submissions 